\title{
Kompetensi Bimbingan Karir Kolaboratif Guru Bk/Konselor SMA Negeri Di Kota Payakumbuh Sumatera Barat
}

\author{
Afdal \\ ${ }^{1}$ Universitas Negeri Padang \\ Article Info \\ Accepted : 08 Desember 2019 \\ Published Online: 27 Desember 2019
}

\begin{abstract}
Abstrak
Keberhasilan pelaksanaan layanan bimbingan dan konseling di sekolah dipengaruhi oleh beberapa faktor, diantaranya adalah kualitas kolaborasi/kerjasama yang dilakukan oleh guru BK/konselor dengan orangtua. Permasalahannya sekarang adalah pelaksanaan kolaboratif/kerjasama dengan orang tua yang disusun dan terprogram dengan baik bukanlah menjadi bagian yang penting dalam pelaksanaan keseluruhan layanan bimbingan dan konseling oleh guru BK/konselor di sekolah. Untuk itu diperlukan pengukuran sejauh mana kompetensi bimbingan karir kolaboratif guru BK/konselor di SMA Negeri Kota Payakumbuh. Sampel dari penelitian ini adalah guru BK/konselor SMA Negeri di kota Payakumbuh yang berjumlah 19 orang yang diambil dengan metode purposive random sampling. Data dikumpulkan dengan menggunakan inventori kompetensi bimbingan karir kolaboratif yang dianalisis secara deskriptif.Hasil penelitian menunjukkan bahwa kompetensi bimbingan karir kolaboratif guru BK/konselor SMA Negeri di Kota Payakumbuh berada dalam kategori umumnya berada pada kategori rendah. Pembahasan dan rekomendasi penelitian di bahas lebih lanjut.
\end{abstract}

Kata Kunci: Hasil belajar, selamatkan makhluk hidup, eksplorasi lingkungan

This is an open access article distributed under the Creative Commons Attribution License, which permits unrestricted use, distribution, and reproduction in any medium, provided the original work is properly cited. C2019 by author

\section{PENDAHULUAN}

Bimbingan karir merupakan salah satu upaya pendidikan yang membantu individu untuk mencapai kompetensi yang diperlukan dalam menghadapi masalah-masalah karir.Bimbingan karir merupakan bagian yang tak terpisahkan dari bimbingan dan konseling komprehensif yang pada awalnya disebut sebagai bimbingan jabatan. Dalam perkembangannya bimbingan jabatan telah diperluas menjadi bimbingan karir yang tidak hanya menekankan pelayanan pada keselarasan ciri diri individu dengan tuntutan jabatan atau pekerjaan, melainkan juga ditekankan pada proses pemilihan dan pengambilan keputusan karir dalam perjalanan hidup siswa (Surya, 1988).Bimbingan karir didefenisikan sebagai bantuan yang diberikan kepada siswa untuk menemukan dan mempersiapkan dirinya agar mampu merencanakan karir dan mengambil keputusan yang tepat sesuai dengan potensinya untuk kehidupan yang lebih baik di masa akan datang sesuai dengan tuntutan perkembangan ilmu pengetahuan dan teknologi.

Tujuan bimbingan karir secara lebih khusus telah digariskan oleh Asosiasi Bimbingan dan Konseling Indonesia (ABKIN) dalam rambu-rambu penyelenggaraan bimbingan dan konseling dalam jalur pendidikan formal, khususnya tujuan layanan yang terkait dengan aspek karir yaitu: (a) memiliki pemahaman diri berkenaan dengan kemampuan, minat dan kepribadian yang terhubung dengan pekerjaan; (b) memiliki pengetahuan mengenai dunia kerja dan informasi karir yang menunjang kematangan kompetensi karir; (c) memiliki sikap positif terhadap dunia kerja. Dalam arti mau bekerja dalam bidang pekerjaan apapun, tanpa merasa rendah diri, 
asal bermakna bagi dirinya dan sesuai dengan norma agama; (d) memahami relevansi kompetensi belajar berupa kemampuan menguasai pelajaran dengan persyaratan keahlian atau keterampilan bidang pekerjaan yang menjadi cita-cita karirnya masa depan; (e) memiliki kemampuan untuk membentuk identitas karir, dengan cara mengenali ciri-ciri pekerjaan, kemampuan (persyaratan) yang dituntut, lingkungan sosio-psikologis pekerjaan, prospek kerja dan kesejahteraan kerja; (f) memiliki kemampuan merencanakan masa depan, yaitu merancang kehidupan secara rasional untuk memperoleh peran tertentu yang sesuai dengan minat, kemampuan dan kondisi kehidupan sosial ekonomi; (g) dapat membantu beberapa pola karir, yaitu kecendrungan arah karir, apabila seorang siswa bercita-cita menjadi seorang guru, maka dia senantiasa harus mengarahkan dirinya kepada sejumlah kegiatan yang relevan dengan karir keguruan tersebut; (h) mengenal keterampilan, kemampuan dan minat. Keberhasilan atau kenyamanan dalam suatu karir amat dipengaruhi oleh kemampuan dan minat yang dimiliki. Oleh karena itu, maka setiap orang perlu memahami kemampuan dan minatnya, dalam bidang pekerjaan apa dia mampu, dan apakah dia berminat terhadap pekerjaan tersebut; (i) memiliki kemampuan atau kematangan untuk mengambil keputusan karir. (Depdiknas, 2008:199-200).Untuk mencapai tujuan pelaksanaan bimbingan karir ini maka diperlukan kerjasama.

Keberhasilan pelaksanaan bimbingan dan konseling di sekolah tidak hanya menjadi tugas dari guru BK/konselor semata, tetapi lebih jauh merupakan tugas bersama antar personel sekolah (baik itu kepala sekolah, guru, wali kelas, petugas administrasi termasuk siswa lainnya) dan lingkungan luar sekolah (lingkungan keluarga dan lingkungan masyarakat). Kerja sama yang baik itu tidak hanya dilakukan dalam internal sekolah saja akan tetapi juga melibatkan berbagai pihak yang memiliki perannya masing-masing. Kerja samayang dilakukan oleh guru $\mathrm{BK} /$ konselor dalam membantu siswa terebut dapat dilakukan dalam bentuk kegiatan kolaboratif.

Kolaboratif dilaksanakan di sekolah dengan alasan bahwa sekolah dan guru BK/konselor tidak bisa berfungsi sendiri/berdiri sendiri untuk memenuhi semua kebutuhan siswa. Pemenuhan kebutuhan siswa untuk mencapai kesuksesan tergantung pada usaha kolaborasi yang dilakukan oleh guru BK/konselor dengan pihakpihak lain.

Guru BK/konselor merupakan individu yang paling mengerti dan memahami sekaligus dapat melaksanakan dengan baik kompetensi berkenaan dengan perkembangan karir dan bimbingan karir.Peranan guru BK/konselor sangatlah pentingdalam pencapaian tujuan bimbingan karir yang sudah dijelaskan sebelumnya.Pentingnya peran guru BK/konselor ini juga menjadi perhatian seandainya tidak ada guru BK/konselor pada satu sekolah untuk melayani perkembangan karir siswa melalui bimbingan karir yang komprehensif.

Tujuan dari penelitian ini adalah untuk memberikan gambaran berkenaan dengan kompetensi bimbingan karir kolaboratif guru BK/konselor SMA Negeri di kota Payakumbuh melalui pertanyaan penelitian "bagaimana profil kompetensi bimbingan karir kolaboratif guru BK/konselor SMA Negeri di Kota Payakumbuh ?". Dengan memperoleh gambaran berkenaan dengan kompetensi guru BK/konselor SMA Negeri di kota Payakumbuh diharapkan para pengambil kebijakan (seperti pengawas sekolah, dinas pendidikan, pemerintah daerah dan perguruan tinggi) dapat memperoleh informasi berkenaan dengan kompetensi bimbingan karir kolaboratif sehingga mampu menyusun program pengembangan kompetensi guru BK/konselor yang sesuai dengan kondisi yang sebenarnya.

\section{METODE}

Pendekatan yang peneliti gunakan adalah pendekatan kualitatif, karena sesuai dengan penelitian tindakan

\section{Sampel Penelitian}

Sampel yang digunakan dalam penelitian ini adalah guru BK/konselor SMA Negeri di kota Payakumbuh yang berjumlah 19 orang yang diambil dengan metode purposive random sampling.

\section{Instrument}

Instrumen yang digunakan dalam penelitian ini adalah angket kompetensi bimbingan karir kolaboratif yang disusun sendiri dengan empat variabel utama penelitian yakni pemahaman tentang siswa, pemahaman tentang bimbingan karir kolaboratif, pemahaman tentang perencanaan karir, dan manajemen program bimbingan karir kolaboratif sebanyak 34 butir dengan pilihan jawaban Ya dan Tidak. Sebelum instrumen disebarkan, peneliti 
melakukan uji validitas dan realibilitas terhadap instrumen yang telah disusun, melalui penilaian dari tiga orang ahli (expert judgement) dalam bidang bimbingan dan konseling serta pengujian secara statistik (statistical validity). Uji statistik yang dilakukan untuk mengukur validitas instrumen adalah analisis korelasi Pearson atau product moment dengan mengkorelasikan masing-masing skor butir soal dengan skor total (item total correlation). Penafsiran yang digunakan dalam analisis ini adalah suatu butir soal dinyatakan valid jika terdapat hubungan yang signifikan positif antara skor butir dan skor total. Butir soal disimpulkan valid apabila rhitung>rtabel., sedangkan uji reliabilitas dilakukan melalui teknik belah dua (split-half technique) dengan bantuan program SPSS for windows 16. Hasil uji statistik menunjukkan instrumen valid dan reliabel dengan nilai reliabilitas sebesar 0.892 .

\section{HASIL DAN PEMBAHASAN}

Secara umum, kompetensi bimbingan karir kolaboratif guru BK/konselor di SMA Negeri di Kota Payakumbuh berada dalam kategori rendah, yang ditandai dengan rendahnya pemahaman tentang siswa, pemahaman tentang perencanaan karir, pemahaman berkenaan dengan bimbingan karir kolaboratif, dan rendahnya pemahaman berkenaan dengan manajemen program bimbingan karir kolaboratif. Secara lebih rinci uraian berkenaan dengan kompetensi bimbingan karir kolaboratif guru BK/konselor SMA Negeri di Kota Payakumbuh dipaparkan dalam tabel 1 berikut ini:

Tabel 1.

Profil Kompetensi Bimbingan Karir Kolaboratif Guru BK/Konselor SMA Negeri di Kota Payakumbuh

\begin{tabular}{ccccc}
\hline Aspek & Kategori & Interval & Frekuensi & Persentase \\
\hline Pemahaman tentang siswa & Tinggi & $\mathrm{X}>3$ & 8 & 42.11 \\
& Rendah & $\mathrm{X} \leq 3$ & 11 & 57.89 \\
Pemahaman tentang perencanaan karir & Tinggi & $\mathrm{X}>4$ & 8 & 42.11 \\
& Rendah & $\mathrm{X} \leq 4$ & 11 & 57.89 \\
Bimbingan karir kolaboratif & Tinggi & $\mathrm{X}>6$ & 10 & 52.63 \\
& Rendah & $\mathrm{X} \leq 6$ & 9 & 47.37 \\
Manajemen Program Bim. Karir Kolaboratif & Tinggi & $\mathrm{X}>5$ & 3 & 15.79 \\
& Rendah & $\mathrm{X} \leq 5$ & 16 & 84.21 \\
& Tinggi & $\mathrm{X}>17$ & 9 & 47.37 \\
Keseluruhan & Rendah & $\mathrm{X} \leq 17$ & 10 & 52.63 \\
& \multicolumn{2}{c}{ Jumlah } & 19 & 100 \\
\hline
\end{tabular}

Tabel 1 memberikan gambaran bahwa kompetensi yang paling rendah dimiliki oleh guru BK/konselor adalah berkenaan dengan manajemen program bimbingan karir kolaboratif.Artinya kompetensi guru $\mathrm{BK} /$ konselor dalam hal penyusunan, pengorganisasian, pelaksanaan dan evaluasi program bimbingan karir kolaboratif masih rendah. Manajemen program bimbingan karir kolaboratif menjadi penting diperhatikan oleh guru BK/konselor mengingat keberhasilan suatu program akan dilihat dari perencanaan, pengorganisasian, pelaksanaan dan evaluasi program tersebut. Pentingnya manajemen program bimbingan juga dikemukakan oleh Suherman (2011:35) yang menyatakan bahwa layanan bimbingan dan konseling akan berjalan dengan efektif dan efisien jika diterapkan berbagai fungsi manajemen bimbingan dan konseling yang meliputi perencanaan, pengorganisasian, pengarahan, koordinasi dan pengawasan.

Jika dilihat lebih rinci, rendahnya kompetensi manajemen bimbingan karir kolaboratif guru $\mathrm{BK} /$ konselor, terdapat pada aspek penyusunan program yang tidak berdasarkan analisis kebutuhan siswa dan orang tua, kurangnya kompetensi dalam pelaksanaan program, penyusunan laporan pelaksanaan program, dan kurangnya kompetensi dalam evaluasi program bimbingan karir kolaboratif baik dalam proses pelaksanaan program maupun pada evaluasi hasil pelaksanaan program. Rendahnya kompetensi manajemen bimbingan karir kolaboratif menjadi perhatian serius dari peneliti dan ilmuwan bimbingan dan konseling, mengingat manajemen program bimbingan dan konseling menjadi ruhnya pelaksanaan bimbingan dan konseling di sekolah.Pentingnya manajemen program tersebut sejalan dengan yang disampaikan oleh Schmidt (2003:109-132) yang menyatakan bahwa keefektifan pelaksanaan bimbingan dan konseling komprehensif di sekolah ditandai dengan kemampuan konselor dalam mengembangkan program bimbingan dan konseling. Kemampuan pengembangan program yang dimaksud meliputi kemampuan dalam hal (a) perencanaan, yang meliputi kemampuan dalam menilai keberlanjutan program saat ini, mencari masukan dan dukungan untuk perubahan, menilai kebutuhan siswa, 
orang tua dan guru serta menetapkan berbagai sumber, (b) pengorganisasian, yang meliputi merumuskan tujuan, penugasan dan pendelegasian tanggung jawab serta kemampuan dalam menjelaskan program kepada pihak yang berkepentingan, (c) pelaksanaan, yang meliputi kemampuan dalam menentukan jadwal dan menetapkan skala prioritas, keseimbangan waktu, konseling, konsultasi, koordinasi dan penilaian terhadap siswa dan (d) kemampuan dalam evaluasi, baik itu evaluasi program, evaluasi proses, evaluasi pelaksanaan mapun tindak lanjut dari evaluasi.

Lebih lanjut, hasil penelitian juga memberikan gambaran bahwa guru BK/konselor memiliki kompetensi yang pada umumnya rendah dalam hal pemahaman terhadap siswa dan pemahaman terhadap konsep dasar perkembangan karir.Pemahaman terhadap siswa secara menyeluruh mengharuskan guru BK/konselor memahami berbagai aspek yang ada dalam diri siswa dan juga berbagai aspek yang berada dalam luar diri siswa (lingkungannya). Pemahaman menyeluruh menjadi penting karena keberhasilan pendidikan siswa tergantung pada berbagai aspek dalam dirinya seperti kecerdasan, bakat, cita-cita, minat, hobi, nilai-nilai yang menjadi sandaran hidup dan yang lain serta dipengaruhi juga oleh berbagai aspek di luar diri seperti dalam lingkungan keluarga, dukungan orang tua terhadap rencana pendidikan dan karirnya. Apabila guru BK/konselor tidak memahami siswa secara menyeluruh maka sangat dimungkinkan guru BK/konselor tidak akan mampu memenuhi kebutuhan siswa akan layanan bimbingan dan konseling yang efektif. Schmidt (2003) yang menyatakan bahwa guru BK/konselor perlu memahami berbagai kebutuhan siswa dengan cara memahami berbagai aspek dalam diri dan lingkungan siswa yang akan mempengaruhi pilihan dan rencana pendidikan dan karirnya. Pemahaman secara dalam dan menyeluruh juga diungkapkan oleh Sukardi (1990:21) yang menyatakan bahwa dalam rangka penyusunan program yang efektif maka guru BK/konselor haruslah memahami secara mendalam berbagai aspek dalam diri siswa, serta juga memahami berbagai aspek di luar diri siswa (lingkungan) yang akan mempengaruhinya.

Hasil penelitian berkenaan dengan kompetensi pemahaman terhadap konsep-konsep perencanaan karir juga menjadi perhatian bagi peneliti, yang menunjukkan kompetensi yang rendah. Kompetensi yang rendah dalam hal pemahaman tentang perencanaan karir itu meliputi kemampuan dalam membantu siswa membuat rencana tindakan (action plan). Membantu siswa dalam merumuskan rencana tindakan menjadi penting dilakukan oleh guru BK/konselor karena dengan adanya rencana tindakan siswa memiliki panduan dalam mengikuti proses pendidikan dan perencanaan karirnya serta siswa akan merasa diberi tanggung jawab untuk melakukan berbagai hal yang sudah dirumuskannya dalam rencana tindakan. Selain rendahnya kompetensi guru $\mathrm{BK} /$ konselor dalam membantu siswa merencanakan tindakan, guru BK/konselor juga kurang memahami hasilhasil penelitian terkini berkenaan dengan perkembangan dan perencanaan karir. Padahal, dengan membaca dan memahami berbagai penelitian terbaru, guru BK/konselor memiliki pemahaman, wawasan, keterampilan, nilai dan sikap yang baru dan luas dalam membantu perkembangan siswa sehingga pelayanan yang diberikan bersifat baru, tidak kaku dan monoton. Keharusan guru BK/konselor dalam memahami berbagai penelitian bimbingan dan konseling ini sejalan dengan Peratuan Menteri Pendidikan Nasional no. 27 tahun 2008 berkenaan dengan standar kualifikasi akademik dan kompetensi konselor yang menyatakan bahwa salah satu kompetensi yang diharapkan ada dalam diri guru BK/konselor adalah kompetensi profesional, khususnya dalam menguasai konsep dan praksis penelitian dalam bimbingan dan konseling. Untuk menguasai konsep dan praksis penelitian tersebut maka guru BK/konselor hendaknya membaca dan memahami berbagai penelitian terbaru berkenaan dengan bimbingan dan konseling, khususnya dalam hal perkembangan dan perencanaan karir.

Berbagai hasil penelitian ini juga memberikan gambaran bahwa hendaknya guru BK/konselor dapat berperan aktif dalam membantu siswa merencanakan karir yang lebih baik, yang tidak hanya semata-mata pada pemilihan pekerjaan semata. Hal ini sejalan dengan pendapat Mitchell dan Krumboltz (Gothard, 2001:24) yang memberikan batasan bahwa bimbingan karir yang dilakukan oleh guru BK/konselor hendaknya membantu individu untuk memahami secara mendalam minat dan kemampuannya, menyiapkan individu untuk perubahan tugas dalam bekerja, meningkatkan kemampuan individu untuk bertindak nyata, dan hendaknya guru BK/konselor memainkan peran yang lebih dalam hal konseling karir yang tidak hanya berperan pada pemilihan pekerjaan semata.

\section{KESIMPULAN}

Penelitian ini juga menemukan bahwa kompetensi guru BK/konselor dalam bimbingan karir kolaboratif masih rendah.Kompetensi yang masih rendah disebabkan oleh kurangnya pengetahuan dan praktik guru BK/konselor dalam bimbingan karir kolaboratif.Pengetahuan dan praktik secara mendalam dalam bimbingan karir kolaboratif yang dimaksud di rinci dalam pemahaman berkenaan dengan diri siswa, pemahaman berkenaan dengan perencanaan karir, pemahaman berkenaan dengan konsep dasar bimbingan karir kolaboratif dan 
pemahaman berkenaan dengan manajemen bimbingan karir kolaboratif. Untuk itu, diperlukan penyiapan calon guru BK/konselor yang memahami keilmuan dan praktik secara mendalam berkenaan dengan bimbingan karir kolaboratif dengan cara melakukan evaluasi, kajian ulang dan revisi konten kurikulum pada mata kuliah yang relevan seperti mata kuliah bimbingan karir. Penelitian ini juga memaparkan pentingnya kerja sama (kolaboratif) yang baik dengan berbagai pihak untuk kesuksesan pelaksanaan program bimbingan dan konseling komprehensif. Untuk itu, calon guru BK/konselor perlu disiapkan dengan pemahaman keilmuan dan praktis tentang pentingnya kolaboratif dalam beberapa matakuliah lain yakni manajemen bimbingan dan konseling, konseling keluarga, layanan konseling di sekolah, praktik bimbingan dan konseling dan matakuliah lain yang relevan.

Lebih lanjut, perlu adanya wadah untuk memikirkan, mengkaji dan memasukkan isu-isu berkenaan dengan keterlibatan orang tua dalam perencanaan karir siswa dengan mengadakan pelatihan/lokakarya bimbingan karir kolaboratif di berbagai jalur, jenjang dan setting pendidikan, baik yang bersifat latihan pra jabatan maupun dalam jabatan (in service training). Hal ini penting dilakukan agar konselor dan calon konselor memahami secara komprehensif bimbingan karir kolaboratif sebagai salah satu upaya dalam memantapkan perencanaan karir siswa.

\section{DAFTAR RUJUKAN}

Afdal.(2015). Model bimbingan karir kolaboratif dalam memantapkan perencanaan karir siswa SMA.Disertasi.Tidak diterbitkan.SPs UPI Bandung.

Depdiknas. (2008). Penataan pendidikan profesional konselor dan layanan bimbingan dan konseling dalam jalur pendidikan formal. Jakarta: Dirjen Dikti Depdiknas.

Glow, K.M., \& Sperhac, A.M. (2003).A community collaborative partnership for the Chicago public schools.The Journal of School Health,73 (10), hlm.395-398.

Gothard, B., dkk. (2001). Career guidance in context.London: Sage.

Schmidt, J.J. (2003). Counseling in schools, essential services and comprehensive programs (Fourth edition).USA: Pearson Education Inc.

Sciarra, J.J. (2003). Counseling in school, essential service and comprehensive programs.Boston: Library of Congress Cataloging.

Sharf, R. S. (2010). Applying career development theory to counseling(Fifth edition). CA USA: Brooks/Cole Cencage Learning.

Suherman, U. (2011). Manajemen bimbingan dan konseling.Bandung: Rizqi Press.

Sukardi, D. K., \& Sumiati, D. M. (1990).Pedoman praktis bimbingan penyuluhan di sekolah.Jakarta: Rineka Cipta.

Surya, M. (1988).Dasar-dasar penyuluhan (konseling).Jakarta: P2LPTK Dikti Depdiknas.

Surya, M. (2012).“Bimbingan Karir Berbasis Nilai-nilai Keluarga.Makalah.Keynote Speaker dalam "Seminar dan Lokakarya Nasional Bimbingan Karir" diselenggarakan oleh Sekolah Pasca Sarjana UPI Bandung bekerja sama dengan MGBK Kabupaten Bandung, bertempat di SMK Negeri 2 Baleendah Kabupaten Bandung, $\quad$ tanggal 27 Nopember 2012.

Surya, M. (2012b). menjadi guru: saripati pengalaman limapuluh tahun berkhidmat sebagai guru. Bandung: Mitra Surya. 